\title{
PENGARUH CROSSWORD PUZZLE BERBASIS 4C TERHADAP HASIL BELAJAR IPA SEKOLAH DASAR
}

\author{
Nur Roudhotul Khasanah ${ }^{1)}$, Atnuri ${ }^{2)}$, Achmad Fanani ${ }^{3)}$ \\ 1Pendidikan Guru Sekolah Dasar, Universitas PGRI Adi Buana Surabaya, Surabaya, Indonesia \\ nurroudhotul45@gmail.com,atnuri@unipasby.ac.id, fanani@unipasby.ac.id
}

\begin{tabular}{|c|c|}
\hline InformasiArtikel & bstrak \\
\hline $\begin{array}{l}\text { Kata Kunci: } \\
\text { crossword puzzle method, } \\
\text { hasil belajar } \\
\text { sekolah dasar. }\end{array}$ & $\begin{array}{l}\text { Pemilihan metode yang tepat selama proses pembelajaran sangat } \\
\text { dibutuhkan oleh pendidik. Metode pembelajaran yang tepat bertujuan } \\
\text { untuk menciptakan suasana belajar yang tidak terlupakan, menyenangkan } \\
\text { dan aktif sehingga siswa dapat berprestasi secara maksimal. Rumusan } \\
\text { masalah dalam penelitian ini adalah pengaruh metode crossword puzzle } \\
\text { 4C dalam proses review Tema } 4 \text { (Sehat Itu Penting) Subtema } 2 \\
\text { (Gangguan Kesehatan pada Organ Peredaran Darah) Pembelajaran } 1 \\
\text { terhadap hasil belajar siswa kelas V dan bagaimana pembelajarannya. } \\
\text { implementasi (kegiatan pendidik dan siswa) dengan metode crossword } \\
\text { puzzle berbasis 4C. Tujuan penelitian ini adalah untuk mengetahui } \\
\text { penerapan metode teka-teki silang dan pengaruh metode teka-teki silang } \\
\text { terhadap hasil belajar. Penelitian ini merupakan penelitian kuantitatif. } \\
\text { Sumber data yang digunakan adalah siswa kelas V SDN Kebondalem } \\
\text { Mojosari yang terdiri dari } 17 \text { siswa laki-laki dan } 12 \text { siswa perempuan. } \\
\text { Teknik pengumpulan data yang digunakan adalah hasil observasi, uji } \\
\text { normalitas, uji homogenitas, uji tan uji hipotesis. Metode teka-teki silang } \\
\text { berbasis } 4 \mathrm{C} \text { mempengaruhi hasil belajar siswa. Hal tersebut dibuktikan } \\
\text { dengan uji-t didapatkan hasil thitung = 26,16, kemudian dicari df }=\text { (N- } \\
\text { 1), (29-1) = 28, dengan menggunakan taraf signifikansi } 5 \% \text {, maka } \\
\text { diperoleh t tabel 2,048 yang berarti thitung }>\text { ttabel. Kesimpulan dari } \\
\text { penelitian ini adalah aktivitas pendidik dalam kategori "sangat baik". }\end{array}$ \\
\hline
\end{tabular}

\section{PENDAHULUAN}

Pendidikan saat ini merupakan faktor terpenting dalam kegiatan pembangunan kemajuan bangsa Indonesia terutama untuk peningkatan sumber daya manusia yang berkreativitas tinggi. Oleh karena itu sangat dibutuhkan perhatian yang sangat serius dari pemerintah terkait pendidikan, apalagi pendidikan saat ini telah memasuki abad 21, dimana persaingan globalisasi atau bisa disebut 4.0 semakin kuat (Rachmadtullah et al., 2020). Untuk mewujudkan pendidikan yang bermutu maka pihak-pihak yang bersangkutan harus memenuhi hak dan kewajiban warga negara untuk mendapatkan layanan pendidikan dan meningkatkan kualitas hidup bangsa Indonesia agar tidak kalah dengan negara berkembang lainnya. 
Menurut Undang-undang yang tertera No.20 tahun 2003 tentang sistem pendidikan nasional menyatakan bahwa pendidikan adalah usaha sadar dan terencana untuk mewujudkan suasana proses belajar agar siswa aktif mengembangkan potensi yang ada pada dirinya untuk memiliki kekuatan spiritual keagamaan, pengendalian diri, kepribadian, kecerdasan, akhlak mulia, serta keterampilan yang diperlukan untuk dirinya, masyarakat, bangsa dan Negara.

Pendidikan Indonesia saat ini sedang mengembangkan dan menerapkan kurikulum 2013 dimana kurikulum ini memiliki keterkaitan dengan pembelajaran tematik terpadu. Dalam pembahasan tema tersebut ditinjau dari berbagai mata pelajaran yaitu, IPS, IPA, B.Indonesia, PPKn, dan Matematika. Hal tersebut dilakukan untuk memberikan pengalaman yang bermakna bagi peserta didik yang dimana proses pembelajaran itu dapat membuat peserta didik aktif dalam pembelajaran. Salah satu mata pelajaran yang memberikan pengalaman langsung dalam pembelajaran adalah IPA. Menurut taksonomi Bloom (dalam Trianto, 2012:142), pem-belajaran IPA dapat memberikan pengetahuan kognitif yang merupakan tujuan utama dari pembelajaran.

Berdasarkan uraian diatas, pendidik harus mampu mengembangkan kegiatan pembelajaran agar peserta didik aktif untuk mengikuti pembelajaran (Setiawan et al., 2020). Salah satu pengembangan kegiatan pembelajaran yaitu pengembangan metode yang membuat peserta didik aktif dan mengalami pembelajaran tidak terlupakan. Metode pembelajaran aktif. Menurut Silberman 2013 menyatakan bahwa salah satu metode aktif dan mejadikan belajar tidak terlupakan adalah Metode Crossword Puzæle (Teka-teki silang).

Menurut Silberman 2013 menyatakan bahwa metode crossword pu₹zle merupakan metode pembelajaran untuk membuat suasana kelas menjadi menyenangkan, serta peserta didik tidak kesulitan dalam memahami dan mengingat materi yang telah diajarkan. Kebanyakan peserta didik mengalami ke-bingungan dalam memahami materi atau konsep materi yang diajarkan khususnya IPA. Sehubungan dengan hal ini untuk mewujudkan pembelajaran yang aktif dapat menerapkan metode crossword puzzle dalam proses pembelajaran IPA.

Metode crossword pu₹zle dapat memberikan nilai positif untuk peserta didik, yaitu peserta didik selalu berlomba untuk mendapatkan jawabannya dengan benar, sehingga muncul persaingan sehat antara perorangan ataupun kelompok. Metode crossword puz:le berbasis 4C, menurut Fanani dkk (2019:11) 4Cini menekankan peserta didik untuk berkolaborasi, komunikasi, berpikir kritis dan kreatif untuk menumbuh kembangkan kecakapan literasi. Dengan hal ini peserta didik dalam proses pembelajaran dengan metode crossword puгzle berbasis 4C menghasilkan hasil belajar yang diharapkan.

Berdasarkan uraian latar belakang di atas, peneliti akan menggunakan crossword puzzle pada pembelajaran IPA kelas V di SDN Kebondalem Mojosari, yang difokuskan pada hasil belajar. Dengan demikian judul yang diambil dalam penelitian ini adalah "Pengaruh Crossword Puz:le berbasis 4C Terhadap Hasil Belajar IPA Peserta Didik Kelas V SDN Kebondalem Mojosari”. Permasalahan inti tersebut diuraikan menjadi beberapa rumusan masalah yaitu Adakah pengaruh metode crossword puzzle (teka-teki silang) berbasis 4 C pada Tema 4 Subtema 2 Pembelajaran1 terhadap hasil belajar IPA peserta didik kelas V di SDN 
Kebondalem Mojosari?. Dan Bagaimana keterlaksanaan (aktivitas pendidik dan peserta didik) dengan metode crossword puzzle (teka-teki silang) berbasis 4C pada Tema 4 Subtema 2 Pembelajaran1 terhadap hasil belajar IPA peserta didik kelas V di SDN Kebondalem Mojosari?

Berdasarkan rumusan masalah yang telah diuraikan dapat dibuat tujuan penelitian secara umum yaitu untuk menciptakan pembelajaran yang menyenangkan dan mempermudah peserta didik dalam mengingat kembali materi yang telah disampaikan. Sehingga peserta didik mampu mencapai tujuan pembelajaran baik aspek kognitif, afektif, maupun psikomotorik.

Manfaat dari penelitian ini adalah merupakan pengembangan pengetahuan tentang metode pembelajaran yang cocok digunakan untuk memperkuat daya ingat peserta didik melalui metode tersebut untuk prestasi belajar peserta didik.

\section{METODE}

Jenis penelitian yang digunakan dalam penelitian ini adalah penelitian kuantitatif. Penelitian ini berlokasi di SDN Kebondalem Mojosari dengan populasi dan sampel seluruh kelas V. Teknik pengumpulan data pada penelitian ini menggunakan observasi dan tes. Instrument yang digunakan adalah lembar observasi aktivitas pendidik dan peserta didik selama proses pembelajaran dan lembar tes digunakan untuk mencari data hasil belajar peserta didik. Teknik analisis data dalam penelitian ini menggunakan Uji Normalitas, Uji Homogenitas, Uji-t. Uji Normalitas dalam peenelitian ini menggunakan uji Chi-Kuadrat. Untuk menguji hipotesis yang diajukan dalam penelitian yang dilakukakan analisis data statistik uji beda atau uji-t. Uji-t memiliki kriteria signifikan (Sig) yang diperoleh lebih dari nilai $\alpha(5 \%)$ yang artinya ada pengaruh terhadap hasil belajar. Jika nilai (Sig) lebih kecil dari $\alpha(5 \%)$ maka artinya tidak ada pengaruh terhadap hasil belajar

Penelitian ini merupakan penelitian Pre-Ekperimental Design dengan bentuk One Grup Pretest-Posttest. Pengumpulan data yang akan digunakan dalam penelitian ini terdiri dari pretest dan posttest. Adapun desain penelitian yang digunakan seperti yang ditunjukkan pada gambar 1 (Sugiyono, 2017).

\section{$\mathrm{O}_{1} \quad \mathrm{X} \quad \mathrm{O}_{2}$}

Gambar 1. Desain penelitian One Grup Pretest-Posttest

Keterangan:

$\mathrm{O}_{1} \quad$ : Nilai pretest (sebelum diberi perlakuan)

$\mathrm{X} \quad$ : Perlakuan menggunakan metode crossword pu₹zle berbasis 4C

$\mathrm{O}_{2} \quad$ : Nilai posttest hasil belajar 


\section{HASIL DAN PEMBAHASAN}

\section{Hasil Penelitian}

Berdasarkan hasil analisis data yang telah dilakukan. Jika di hitung dengan manual maka diperoleh hasil sebagai berikut.

\section{Uji Normalitas}

Uji normalitas dalam penelitian ini menggunakan uji Chi-Kuadrat. Dengan kriteria pengujian adalah apabila nilai signifikasi (Sig) yang diperoleh lebih dari nilai $\alpha(5 \%)$, maka sampel dikatakan berasal dari populasi yang berdistribusi normal. Namun jika nilai signifikasi yang diperoleh lebih kecil dari $\alpha$ (5\%), maka sampel dari populasi dikatakan tidak berdistribusi normal.

\begin{tabular}{cccc}
\multicolumn{4}{c}{ Tabel 1. Tabel $\mathbf{X}_{\text {hitung dan } \mathrm{X}_{\text {tabel }}}$} \\
\hline $\mathbf{X}_{\text {hitung }}$ Pretest & $\mathbf{X}_{\text {hitung }}$ Posttest & $\mathbf{X}_{\text {tabel }}$ Pretest & $\mathbf{X}_{\text {tabel }}$ Posttest \\
\hline$-53,77$ & $-23,59$ & 7,815 & 7,815 \\
\hline
\end{tabular}

Mengetahui data berdistribusi normal dari tabel diatas pretest dan posttest yang telah dikerjakan oleh peserta didik, maka hasil keputusan uji dapat disimpulkan bahwa kedua uji normalitas pretest dan posttest dinyatakan normal. Dilihat dari uji normalitas pretest memperoleh hasil data akhir berdistribusi normal, karena $\mathrm{X}^{2}$ hitung $\leq \mathrm{X}_{\text {tabel }}^{2}$ atau $-53,77 \leq 7,815$ dan uji normalitas posttets memperoleh hasil data akhir berdistribusi normal, karena $\mathrm{X}_{\text {hitung }} \leq \mathrm{X}_{\text {tabel }}$ atau $-23,59 \leq 7,815$.

\section{Uji Homogenitas}

Uji homogenitas dalam penelitian ini memiliki kriteria pengujian adalah apabila nilai signifikasi (Sig) yang diperoleh lebih dari nilai $\alpha(5 \%)$, maka sampel dikatakan berasal dari populasi yang bersifat homogen. Namun jika nilai signifikasi yang diperoleh lebih kecil dari $\alpha(5 \%)$, maka sampel dari populasi dikatakan tidak bersifat homogen.

\begin{tabular}{cc}
\multicolumn{2}{c}{ Tabel 2. Tabel $\mathrm{F}_{\text {hitung }}$ dan $\mathrm{F}_{\text {tabel }}$} \\
\hline $\mathbf{F}_{\text {hitung }}$ & $\mathbf{F}_{\text {tabel }}$ \\
\hline 1,64 & 1,88 \\
\hline
\end{tabular}

Mengetahui data besifat homogen dari tes pretest dan posttest yang telah dikerjakan oleh peserta didik memperoleh perhitungan yang sudah dilakukan dengan harga $F_{h i t u n g}$ sebesar 1,67. Kemudian dibandingkan dengan harga $\mathrm{F}_{\text {tabel }}$ dengan dk pembilang 28 dan dk penyebut 28 serta taraf signifikan $5 \%$ harga $\mathrm{F}_{\text {tabel }}$ adalah 1,88 karena $\mathrm{F}_{\text {hitung }} \leq \mathrm{F}_{\text {tabel }}(1,67 \leq 1,88)$ maka dapat disimpulkan nilai pretest dan posttest bersifat Homogen.

\section{Uji-t}

Uji-t dalam penelitian ini memiliki kriteria pengujian adalah apabila nilai signifikasi (Sig) yang diperoleh lebih dari nilai $\alpha(5 \%)$, maka artinya ada pengaruh model pembelajaran metode crossword pu₹zle berbasis 4C terhadap hasil belajar peserta didik kelas V di SDN Kebondalem Mojosari. Namun jika nilai signifikasi yang 
diperoleh lebih kecil dari $\alpha$ (5\%), maka artinya tidak ada pengaruh metode crossword puzzle berbasis 4C terhadap hasil belajar peserta didik kelas V di SDN Kebondalem Mojosari.

Berdasarkan perhitungan yang telah dilakukan dengan menggunakan rumus uji-t untuk desain One GrupPretest Posttest maka didapat $t_{\text {hitung }}=26,16$. Kemudian dibandingkan dengan $t_{\text {tabel }}$ dengan taraf signifikan $5 \%$ mendapat 2,048, karena $t_{\text {hitung }}>\mathrm{t}_{\text {tabel }}$ atau 26,16 $>2,048$ maka $\mathrm{H}_{0}$ ditolak yang artinya ada pengaruh metode crosswordpPuzzle berbasis terhadap hasil belajar IPA peserta didik kelas V di SDN Kebondalem Mojosari Tahun 2019-2020.

\section{Pembahasan}

Berdasarkan hasil penyajian data pada sub bab sebelumnya peneliti akan memberikan penjelasan atas hasil yang telah peneliti analisis dengan teori-teori yang dikembangkan para ahli beserta hasil penelitian terdahulu. Pembahasan yang pertama yaitu Penerapan Metode crossword puzzle Berbasis 4C Terhadap Hasil Belajar IPA Peserta Didik Kelas V SDN Kebondalem yang dapat dilihat dari aktivitas pendidik dan pembahasan yang kedua yaitu ada Pengaruh Metode Crossword Pu₹zle Berbasis 4C Terhadap Hasil Belajar IPA Peserta Didik Kelas V SDN Kebondalem.

Proses penerapan metode crossword puzzle berbasis 4C dalam pembelajaran IPA kelas V SDN Kebondalem Mojosari dapat dilihat dari aktivitas yang dilakukan pendidik dan peserta didik selama proses pembelajaran. Peneliti menggunakan instrument lembar observasi pendidik dan peserta didik sebagai tolak ukur keberhasilan dalam metode crossword pu₹:le. Observasi pendidik dan peserta didik sesuai dengan sintaks metode crossword puz:le Silberman (2013:256), komponen sintaks dari metode tersebut setiap aktivitasnya berorientasi pada karakteristik 4C.

Tahap yang pertama adalah pendidik menjelaskan beberapa istilah atau nama-nama penting yang terkait dengan mata pelajaran yang telah diajarkan, dimana peserta didik dituntut aktif dalam pembelajaran untuk berpikir kritis menetukan kata lunci yang dibuat dalam Crossword Puzile dengan materi penyebab dan macam-macam gangguan peredran manusia yang telah diajarkan. Tahap yang kedua adalah memberikan contoh untuk menyusun sebuah teka-teki silang sederhana, dimana peserta didik dapat mendesain teka-teki silang tersebut semenarik mungkin mendatar atau menurun.

Tahap ketiga adalah pendidik menjelaskan cara menyusun kata-kata pemandu pengisian teka-teki silang dengan menggunkan definisi singkat, sebuah kategori yang cocok dengan unsurnya, sebuah contoh dan lawan katanya. Tahap yang keempat adalah dimana peserta didik saling berkomunikasi dan bekerjasama dalam kelompok untuk menentukan penggunaan keterangan-keterangan yang dapat dipahami pembaca atau peserta didik itu sendiri. Tahap yang kelima adalah pendidik meminta peserta didik untuk membuat Crossword Puz:le secara kelompok yang sudah ditetapkan. Tahap keenam adalah pendidik menetapkan batas waktu pengerjaan kepada peserta didik. Kemudian memberikan penghargaan kepada individu atau tim yang paling banyak memiliki jawaban benar. Pendidik memberikan penilaian kepada peserta didik setelah selesai tugasnya, tugas tersebut ditukar kepada kelompok lain guna mengetahui tingkat kejelasan dan pemahaman dalam membuat Crossword Pu§le serta menjawab teka-teki tersebut. Kelompok yang paling banyak menjawab 
benar akan mendapatkan reward. Tahap ketujuh adalah pendidik dan peserta didik mendiskusikan hasil menjawab teka-teki silang perkelompok.

Berdasarkan hasil analisis data observasi pendidik dan peserta didik dalam menerapkan pembelajaran menggunakan metode Crossword Pu₹zle Berbasis 4C menunjukkan hasil presentase sebesar 93 untuk pendidik dan observasi aktivitas peserta didik mendapatkan presentase $91 \%$ dari 7 aspek yang diamati dan menunjukkan kategori "Sangat Baik". Hal tersebut telah dibuktikan melalui tabel 4.5 yang berisi data aktivitas pendidik dan tabel 4.6 yang berisi data aktivitas peserta didik. Artinya pendidik berhasil menerapkan metode Crossword Puz:le berbasis 4C.

Penelitian ini juga diperkuat dengan penelitian terdahulu yang dilakukan oleh Mardhatilah, Henra Saputra Tanjung yang berjudul "Pengaruh Penerapan Metode Crossword Pu₹zle Terhadap Keterampilan Sosial Pada Materi Keragaman Suku Bangsa Dan Budaya di Indonesia Siswa Kelas V SD Negeri Suak Pandan" (2018). Berdasarkan hasil penelitian tersebut menyatakan metode crossword puz:zle terjadi perubahan secara signifikan terhadap keterampilan sosial.

Sebelum menerapkan metode crossword puz:le terhadap peserta didik kelas V SDN Kebondalem Mojosari dilakukan pretest terlebih dahulu untuk mengetahui hasil sebelum dilakukan penerapan metode crossword puzzle. Setelah dilakukan pretest selanjutnya dilakukan posttest dimana peserta didik kelas V SDN Kebondalem mendaptkan perlakuan khusus yaitu menggunakan metode crossword puzzle. Dan dari kedua hasil tes tersebut, dilakukan perhitungan untuk mengetahui diterima atau ditolaknya dari pegaruh metode crossword puzzle. Dapat dilihat dari uji-t yang dilakukan memperoleh hasil sebesar 26,16 dan peneliti melakukan uji hipotesis dengan cara membandingkan $t_{\text {tabel }}$ dengan taraf signifikan 5\% maka didapat 2,048 karena $t_{\text {hitung }}>\mathrm{t}_{\text {tabelatau }}$ 26,16 $>$ 2,048 maka $\mathrm{H}_{0}$ ditolak dan Ha diterima yang artinya ada pengaruh Crossword Pu₹zle berbasis 4C terhadap hasil belajar IPA peserta didik kelas V SDN Kebondalem Mojosari.

Terjadinya pengaruh crossword puz:le berbasis $4 \mathrm{c}$ terhadap hasil belajar IPA peserta didik kelas V SDN Kebondalem Mojosari disebabkan oleh karakteristik dalam setiap langkah-langkah metode crossword puzzle berbasis 4C dimana peserta didik kelas $\mathrm{V}$ lebih tertarik dengan pembelajaran teka-teki silang sehingga peserta didik terlibat secara aktif dan mengalami pembelajaran yang menyenangkan. Sehingga peserta didik tidak merasa bosan. Hal ini sesuai dengan pendapat Silberman (dalam Ridwan, 2019:55), mendeskripsikan bahawa peserta didik melakukan banyak kegiatan saat belajar secara aktif. Peserta didik menggunakan pemikirannya untuk mempelajari ide-ide, memecahkan permasalahan, dan menerapkan apa yang mereka pelajari. Belajar secara aktif akan membuat peserta didik penuh semangat dan merasa senang dalam belajar.

Metode crossword puz:le ini, melatih peserta didik untuk mengingat dan memahami konsep-konsep yang terkandung dalam materi pembelajaran sehingga peserta didik mampu mengembangkan motivasi belajarnya dan mengalami belajar tak terlupakan. Hal ini diperkuat dengan pendapat Silberman (2013:256) yaitu metode crossword pu₹zle menjadikan belajar tidak terlupakan dan membuat suasana kelas menjadi menyenang-kan. Sehingga mencapai tujuan pembelajaran yang diharapkan.

Penelitian ini juga diperkuat dengan penelitian yang terdahulu yang dilakukan oleh Maria Desidaria Noge yang berjudul "Pengaruh Metode Crossword Puz:le Berbasis Media Realia Terhadap Penguasaan 
Kosakata Bahasa Inggris Siswa Kelas IV Sekolah Dasar Di Gugus II Kecamatan Jerebuu" (2019). Hasil penelitian ini berpengaruh terhadap hasil belajar Bahasa Inggris siswa kelas IV Gugus II Kecamatan Jerebuu. Hal ini terbukti dengan hasil penelitian diperoleh rata-rata hasil belajar Bahasa Inggris kelompok eksperimen lebih besar dari rata-rata hasil belajar kelompok kontrol yaitu 0,53>0,37. Hasil thitung $=5,673>$ $\mathrm{t}_{\text {tabel }}=2,052$, dengan derajat $(\mathrm{db})=\mathrm{n} 1+\mathrm{n} 2-2=27$ dan taraf signifikan $5 \%(\alpha=0,05)$.

Berdasarkan urian diatas, pembelajaran pada kelas V SDN kebondalem menunjukkan hasil yang berbeda sebelum dan sesudah diterapkan metode crossword puz:le. Hasil tes belajar peserta didik menunjukkan secara spesifik lebih tinggi setelah diterapkan metode crossword puгzlle. Dengan demikian dapat disimpulkan bahwa terdapat pengaruh yang signifikan dari penerapan metode crossword puzzle terhadap hasil belajar IPA peserta didik kelas V SDN Kebondalem Mojosari.

\section{KESIMPULAN}

Berdasarkan hasil analisis data yang diperoleh dalam penelitian ini dapat disimpulkan sebagai beriku: Hasil dari observasi akivitas pendidik selama proses penerapan metode crossword puzzle berbasis 4C pada peserta didik kelas V SDN Kebondalem Mojosari diperoleh hasil 93 dari 7 kriteria sehingga menunjukkan hasil yang sangat baik. Proses pembelajaran berjalan sesuai dengan sintaks dan indikator metode pembelajaran crossword puz:le menjadikan pembelajaran yang aktif, bermakna, belajar tak terlupakan dan menyenangkan. Hasil dari observasi akivitas peserta didik selama proses penerapan metode crossword puzzle berbasis 4C peserta didik kelas V SDN SDN Kebondalem Mojosari diperoleh hasil 91\% dari 7 kriteria sehingga menunjukkan hasil yang sangat baik. Proses pembelajaran berjalan sesuai dengan sintaks dan indikator metode pembelajaran crossword pu:zle menjadikan pembelajaran yang aktif, bermakna, belajar tak terlupakan dan menyenangkan. Dan hasil dari perolehan masing-masing uji diantarnya: Uji Normalitas dari hasil pretest $-53,77 \leq 7,815$ berdistribusi normal, karena $\mathrm{X}_{2}$ hitung $\leq \mathrm{X}_{2}$ tabel dan dari hasil posttest $-23,59$ $\leq 7,815$ karena $\mathrm{X}_{\text {2hitung }} \leq \mathrm{X}_{\text {2tabel. }}$ Uji Homogenitas memperoleh hasil 1,67 $\leq 1,88$ karena $F_{\text {hitung }} \leq \mathrm{F}_{\text {tabel }}$ dinyatakan homogen. Dari Uji t diperoleh hasil sebesar 26,16 dan Uji Hipotesis memperoleh kesimpulan uji $\mathrm{t}$ maka didapat thitung $=26,16$. Kemudian dibandingkan dengan $\mathrm{t}_{\text {tabel }}$ dengan taraf signifikan $5 \%$ mendapat 2,048, karena $t_{\text {hitung }}>\mathrm{t}_{\text {tabel }}$ atau 26,16 $>2,048$ maka $\mathrm{H}_{0}$ ditolak yang artinya ada pengaruh metode crossword Puzzle berbasis 4C terhadap hasil belajar IPA peserta didik kelas V di SDN Kebondalem Mojosari Tahun 2019-2020. Peserta didik mengalami belajar yang tak terlupakan dengan menerapkan crossword pu₹:le sehingga pembelajaran menyenangkan dan bermakna. Dengan fasilitasi sarana prasarana sekolah yang memadai serta mengembangkan metode atau model pembelajaran yang tepat, pembelajaran lebih efektif dan efisien. Sehingga pembelajaran yang diterima oleh peserta didik meningkat.

\section{DAFTAR PUSTAKA}

Fanani, Achmad dkk. 2019. Analisis Pembelajaran Berbasis Pem-belajaran Abad 21. Surabaya: Adi Buana University Press

Rachmadtullah, R., Yustitia, V., Setiawan, B., Mahya Fanny, A., Pramulia, P., Susiloningsih, W., Tur Rosidah, C., Prastyo, D., \& Ardhian, T. (2020). The Challenge Of Elementary School Teachers To Encounter Superior Generation In The 4.0 Industrial Revolution: Study Literature. International Journal 
of Scientific \& Technology Research, 9(4), 1879-1882. www.ijstr.org

Setiawan, B., Rachmadtullah, R., \& Iasha, V. (2020). Problem-Solving Method: The Effectiveness of The Pre-service Elementary Education Teacher Activeness in The Concept of Physics Content. Jumal Basicedu, 4(4), 1074-1083.

Silberman, Melvin L. 2013. Active Learning 101 Cara Belajar Siswa Aktif. Bandung: Penerbit Nuansa Cendekia Sugiyono. 2017. Metode Penelitian Kuantitatif, Kualitatif, dan ReDD. Bandung: Alfabeta

Trianto. 2012. Model Pembelajaran Terpadu. Jakarta: BumiAksara

Undang-undang Republik Indonesia Nomor 20 Tahun 2003 Tentang Sistem Pendidikan Nasional

Noge, M Desidaria. 2019. "Pengaruh Metode Crossword Pu₹zle Berbasis Media Realia Terhadap Penguasaan Kosakata Bahasa Inggris Siswa Kelas IV Sekolah Dasar di Gugus II Kecamatan Jebrebuu”. Vol 3, No 1.

Mardhatilah, HenraSaputra. 2018."Pengaruh PenerapanMetode Crossword Puzzle Terhadap Keterampilan Sosial Pada Materi Keragaman Suku Bangsa Dan Budaya di Indonesia Siswa Kelas V SD Negeri Suak Pandan". Vol 5, No 2. 